\title{
REALISASI POLITIK ETIS DI BOJONEGORO PADA AWAL ABAD XX : Kajian Sosial Ekonomi
}

\author{
Mudji Hartono \\ Program Studi Ilmu Sejarah \\ Fakultas Ilmu Sosial Universitas Negeri Yogyakarta
}

\begin{abstract}
ABSTRAK
Sebagaimana diketahui bahwa Kemerosotan kesejahteraan Penduduk pribumi Pulau Jawa melatarbelakangi lahirnya Politik Etis. Ratu Wihelmina, dalam pidao pembukaan di parlemen Belanda mengatakan bahwa Pemerintah kolonial Belanda di penghujung era Sistem Liberal. Memiliki tugas Moral, di dalam pidato tersebut tersirat pengakuan bahwa Pmerintah Belanda memiliki Hutang Budi (Ereschuld) yang merupakan tujuan utama, yaitu memperbaiki ekonomi koloni dan penduduk Pribumi dengan melaksanakan pembangunan Irigasi, Edukasi, dan Emigrasi. Bojonegoro merupakan salah satu daerah di Pulau Jawa yang mengalami kemerosotan kesejahteraanan. De Vries dalam pidatonya di depan para Guru Besar di Belanda menyatakan bahwa Bojonegoro, Cirebon Selatan, dan Pekalongan Selatan merupakan daerah yang "menuju kematian". Selain itu Penders mengatakan bahwa kemiskinan di Bojonegoro itu bersifat endemis. Sehubungan dengan itu, Maka pada tahun 1906, Residen Rembang, Fraenkel melaporkan kepada Gubernur Jendral bahwa Bojonegoro dan Blora dilanda kemiskinan yang gawat.

Tujuan penulisan ini adalah untuk mengungkap seberapa jauh politik Etis dilaksanakan di Bojonegoro? kiranya permasalahan ini sampai saat sekarang masih relevan untuk diungkapkan, karena dari zaman kolonial Belanda hingga kini terdapat pola bencana yang sama dan berkelanjutan. Selain itu tulisan ini bermaksud untuk mensintesis fakta-fakta tentang Realisasi Kebijaksanaan Etis di Bojonegoro. Dalam mengungkap permasalahan tersebut di atas pendekatan sosiologi turut menerangkan seberapa jauh politik etis dilaksanakan di Bojonegoro.

Hasil kajian menunjukkan bahwa Pemerintah Kolonial Belanda benar-benar merealisasikan Politik Etis di Bojonegoro, bahkan Pemerintah Hindia Belanda tampak lebih aktif dari pada rakyat dalam menghadapi kemerosotan ekonomi didaerah itu. Realisasi Politik Etis, khususnya aspek irigasi dan edukasi begitu tampak jelas dilaksanakan di Bojonegoro, sedangkan untuk program transmigrasi, dapat dikatakan tidak begitu populer, sehingga Pemerintah Hindia Belanda tidak berhasil memindahkan sebagian penduduk Bojonegoro ke tempat lain, ini berarti pemerintah gagal mengurangi kepadatan penduduk di Bojonegoro. Penduduk Residensi Rembang, termasuk juga Bojonegoro yang melakukan perpindahan ke luar Jawa tidak begitu besar. Jumlah orang yang pindah ke luar Jawa lebih kecil dibandingkan dengan jumlah orang yang berpindah ke Semarang. Penduduk Bojonegoro tidak berniat melakukan transmigrasi ke luar Jawa, Mereka kebanyakan enggan meninggalkan daerahnya untuk pergi jauh sebab tanahnya dianggap masih dapat menghidupi keluarga, maka tidak tertarik oleh iming-iming memperoleh tanah secara cuma-cuma dari pemerintah jika ikut bertransmigrasi.
\end{abstract}




\section{PENDAHULUAN}

Kabupaten Bojonegoro berada di wilayah Propinsi Jawa Timur. Namun pada masa kolonial Belanda, Bojonegoro berada di wilayah Jawa Tengah, Letak Bojonegoro berhampiran dengan Sungai Bengawan Solo, Bojonegoro terletak di sebelah timur bagian Jawa Tengah bagian utara. Pada tahun 1900 wilayah Bojonegoro merupakkan bagian dari Residensi Rembang, tetapi pada 1 juli 1928 Bojonegoro dipisahkan dari Residensi Rembang, dan menjadi Residensi tersendiri dengan nama Residensi Bojonegoro, yang wilayahnya meliputi Kabupaten Bojonegoro dan Kabupaten Tuban. Kemudian tahun 1931 Bojonegoro dimasukan dalam Wilayah Residensi Gresik. ${ }^{1}$ Sebelumnya, Secara yuridis Bojonegoro adalah wilayah Kasultanan Yogyakarta, yaitu yang disebut bagian Mancanegara (wilayah

${ }^{1}$ Penders, C.L.M Bojonegoro 1900-1942. A.Story of EndemicPoverty in. North East Java Indonesia. Singapura:Gunung Agung,1984.h, 32- luar) yang secara prinsipiil sampai tahun 1810. Selanjutnya pada tahun 1811-1816 Mancanegara di bawah kontrol langsung pemerintah Batavia, sementara itu Bojonegoro diserahkan Inggris kepada seorang putra Noto Kusumo (yang bernama Paku Alam).

$$
\text { Perlu diketahui bahwa }
$$

Bojonegoro dipilih sebagai wilayah fokus Studi. Ini karena Bojonegoro disebut-sebut sebagai daerah yang secara sosial-ekonomi sangat terpuruk, karena setiap tahun dilanda bencana banjir dan kekeringan yang mengakibatkan produktifitas pertanian sangat rendah dan akibatnya sering kali penduduknya mengalami kemiskinan yang endemis serta kelaparan. ${ }^{2}$ Masalah Kemerosotan kemakmuran penduduk Bojonegoro bersifat endemik Kemiskinan terjadi secara kronis. Berdasarkan data-data yang diketemukan keadaan seperti itu sudah

\footnotetext{
${ }^{2}$ Penders, C.L.M Bojonegoro 1900-1942. A.Story of EndemicPoverty in. North East Java Indonesia. Singapura:Gunung Agung,1984.h, 32-34.
} 
terjadi pada tahun 1888, 1889, 1890 dan $1891^{3}$, Kehancuran Bojonegoro tahun 1890 disebabkan oleh bencana banjir Sungai Bengawan Solo (bulan Februari). Bencana banjir itu menghanyutkan rumah-rumah penduduk, jalan-jalan dan jembatan serta merusakan tanaman pangan. $^{4}$ Banjir dan kemarau mengakibatkan kegagalan panen, gagal panen yang terjadi berturut-turut, seperti tahun 1904 hingga 1906, mengakibatkan kekurangan bahan makanan dan selanjutnya terjadi kelaparan. Keadaan seperti itu pernah dilaporkan oleh Residen Rembang, Fraenkel. Kepada Gubernur Jenderal pada tahun 1906, namun Pemerintah pusat menganggap belum begitu mengkhawatirkan. ${ }^{5}$

Sehinga Pemerintah Residensi segera mengambil langkah-langkah yang berkaitan dengan pengadaan persediaan bahan pangan. Kemudian langkah untuk kepentingan jangka panjang baru di

${ }^{3}$ AVRR. 1891.

${ }^{4}$ Ibid.

${ }^{5}$ Mudji Hartono,Tesis.h. 181-182. programkan pada waktu berikutnya, seperti perbaikan sistem irigasi, memajukan pendidikan dan transmigrasi.

Tujuan penulisan ini adalah untuk mensintesiskan fakta-fakta sejarah tentang pelaksanaan Politik Etis di Bojonegoro dan sekaligus untuk menunjukkan sebuah bukti, bahwa sejarah Indonesia pada masa kolonial tidak saja melulu berisi tentang eksploatasi Pemerintah Hindia Belanda terhadap penduduk Pribumi dan koloninya, melainkan juga adanya usaha-usaha Pemerintah kolonial Belanda dalam memperbaiki ekonomi rakyat, khususnya di Bojonegoro. Memang Eksploatasi Pemerintah Hindia Belanda terhadap koloni merupakan fakta historis yang sulit terbantahkan. Namun tulisan ini bermaksud untuk menunjukkan bahwa pelaksanaan Politik Etis di Bojonegoro juga merupakan fakta historis yang amat kuat. Selain itu 
juga untuk membuktikan bahwa Politik

Etis direalisasikan dengan serius di Bojonegoro. Perlu diketahui bahwa penulisan ini tidak bermaksud memberikan penilaian tentang berhasil tidaknya pelaksanaan Politik Etis di Bojonegoro. Sehingga berbeda dengan apa yang dilakukan oleh Penders dalam karyanya yang berjudul : Bojonegoro 1900-1942. A.Story of EndemicPoverty in. North East Java Indonesia. Singapura: Gunung Agung,1984. Hal ini dapat dilihat pada bagian Epilognya, dalam bagian terakhir tulisannya itu Penders menilai bahwa secara substansial Politik Etis gagal meningkatkan standar hidup penduduk Bojonegoro.

Dengan demikian Tulisan ini tidak memiliki prasangka buruk terhadap Pemerintah kolonial Belanda, yang mungkin berbeda dengan kebanyakan tulisan yang mempunyai Stigma buruk terhadap pemerintah
Kolonial Belanda. Permasalahan tersebut masih relevan untuk diungkapkan, karena pada saat sekarang di Bojonegoro terdapat pola bencana yang sama dan berkelanjutan seperti terjadi pada zaman kolonial Belanda. Bagaimanapun Bojonegoro merupakan wilayah fokus Studi ini.

$$
\text { Pada tahun } 1900 \text { wilayah }
$$

Bojonegoro merupakan bagian dari Residensi Rembang, tetapi sejak tanggal 1 juli 1928 Bojonegoro dipisahkan dari Residensi Rembang, dan menjadi Residensi tersendiri dengan nama Residensi Bojonegoro, yang wilayahnya meliputi Kabupaten Bojonegoro dan Kabupaten Tuban. Kemudian tahun 1931 Bojonegoro dimasukan dalam Wilayah Residensi Gresik. Sebelumnya, Secara yuridis Bojonegoro adalah wilayah kasultanan Yogyakarta, yaitu yang disebut bagian Mancanegara (wilayah luar) yang secara prinsipiil sampai tahun 1810. Selanjutnya pada 
tahun 1811-1816 Mancanegara

dibawah kontrol langsung pemerintah

Batavia, sementara itu Bojonegoro diserahkan Inggris kepada seorang putra

Noto Kusumo (yang bernama Paku Alam). ${ }^{6} \quad$ Perlu diketahui bahwa

Bojonegoro dipilih sebagai wilayah fokus Studi. Ini karena Bojonegoro disebut-sebut sebagai daerah yang sangat terpuruk, sering kali penduduknya mengalami kelaparan. ${ }^{7}$ Sehubungan dengan itu Penders menyatakan bahwa Bojonegoro sebagai daerah di wilayah karesidenan Rembang yang termiskin, terbelakang dalam soal sosial-ekonominya. ${ }^{8}$ sedangkan Prof de Vries menyebutnya Bojonegoro sebagai daerah yang menuju "kematian". Sama Seperti daerah Cirebon Selatan dan PekalonganSelatan. ${ }^{9} \quad$ Walaupun demikian Bojonegoro merupakan

\footnotetext{
${ }^{6}$ Penders, C.L.M. Bojonegoro 1900-1942. A.Story of EndemicPoverty in. North East Java Indonesia. Loc.Cit.

${ }^{7}$ Penders, C.L.M1984, Ibid.,h.3.

${ }^{8}$ MudjiHartono. Tesis,h.47.

9 Vries de E.Masalah-masalah Petani Jawa. Jakarta:Bhratara, 1972.,h.19.
}

sumber pendapatan tambahan Pemerintah Kolonial Belanda, yaitu dari produk kayu jatinya yang berkualitas tinggi. Berdasarkan pernyataan Penders dan de Vries tersebut serta laporan Residen Rembang, Fraenkel kepada gubernur Jendral maka dapat diketahui bahwa kondisi ekonomi Bojonegoro sangat buruk. Sudah tentu kondisi Bojonegoro yang mengkhawatirkan ini menjadi perhatian yang serius dari pemerintah kolonial Belanda yang komitmen dengan perbaikan kesejahteraan. Melalui Kebijaksanaan Etiknya. Hal ini mengacu pada pidato Ratu Wihelmina, dalam pembukaan di parlemen Belanda yang mengatakan bahwa Pemerintah kolonial Belanda di penghujung era Sistem Liberal. Memiliki tugas Moral, yang merupakan tujuan utama, yaitu memperbaiki ekonomi koloni dan penduduk Pribumi. Dalam pidato itu disebut juga Ereschuld ( hutang budi), Utang Budi itu 
didasarkan pada fakta bahwa selama abad ke-19 koloni Hindia Belanda telah mengumpulkan pajak yang kemudian dikirimkan ke Negeri Belanda guna membantu neraca anggaran belanja. Bagi Hindia Belanda pengakuan tentang Utang Budi dari Ratu Belanda tersebut penting artinya karena sebelumnya dana yang dikirimkan dari daerah ke pusat tidak ada yang kembali tetapi sejak politik Etis diterapkan pemerintah memberikan bantuan kepada Hindia Belanda. Kedua, Belanda melihat adanya pemerintah di Hindia Belanda yang mengurus kemakmuran rakyat. Berarti pemerintah aktif menaikkan taraf hidup rakyat. Resep Politik Etis ada dalam semboyan tiga program, yaitu: pembangunan Irigasi, Edukasi, dan Emigrasi. Gubernur Jenderal Idenburg, yang diangkat (1916-1921). dari partai politik kristen. memiliki tugas utama melaksanakan Politik Etis karena kebijaksanaan sebelumnya telah menyebabkan kekurangan kemakmuran di Hindia Belanda. Selain itu Perbaikan kesejahteraan penduduk Jawa juga dibicarakan oleh Roseboom, Gubernur Jenderal dengan Menteri Tanah Jajahan, Idenburg $^{10}$ dalam Surat menyuratnya. ${ }^{11}$ Adapun inti pembicaraannya adalah tentang apa saja yang harus mendapatkan perhatian untuk memperbaiki ekonomi penduduk Jawa perhatian diutamakan pada soal Irigasi, edukasi, emigrasi, pertanian, perbaikan jalan-jalan, kredit pertanian dan memajukan peningkatan Indstri. ${ }^{12}$

I. PERBAIKAN

SISTEM PERTANIAN

Perbaikan Sistem Pertanian sebagai bagian dari Pelaksanaan Politik Etis, karena bertujuan untuk meningkatkan kesejahteraan penduduk Program Peningkatan Pertanian merupakan dukungan terhadap soal sosial ekonomi dari pembaharuan sistem

\footnotetext{
${ }^{10}$ Mudji Hartono, Tesis.,h.2-3.

${ }^{11}$ Ibid.

12 Ibid.
} 
Etikal. Langkah pertama dalam memperbaiki sistem pertanian adalah perbaikan sistem irigasi. Namun pihak Departemen Pertanian di Bogor pesimis dengan langkah itu, dan lebih setuju dengan pembangunan Sekolah Pertanian desa (Desa Lanbouwscholen).

Pada September 1899 Direktur Institut Penelitian Botanical Nasional di Bogor diarahkan oleh pemerintah kolonial untuk menyusun dan mengurus bidang-bidang tanah yang dialokasikan untuk percobaan tanaman 1907-1910. Di Bojonegoro digunakan untuk Percobaan tanaman padi, kopi, dan randu. Secara keseluruan percobaan itu mengalami kegagalan karena sulit merubah pembawaan petani yang konservatif dan memakai metode tradisional, ${ }^{13}$ namun percobaan tanaman padi di Bojonegoro dapat dikatakan berhasil, akan tetapi petani tidak dapat melaksanakan hasil percobaan tersebut karean terbentur pada masalah dana untuk membeli bibit

${ }^{13}$ Penders.OpCit.,h.49. yang baik, dan pupuk kimia. Upaya pemerintah yang lain adalah Peningkatan hasil penduduk yang dimulai pada akhir tahun 1936, Bojonegoro mendapat perhatian khusus, yaitu diputuskan untuk mendapatkan "perawatan istimewa" dan usaha sistematis serta bantuan pemerintah untuk meningkatkan hasil penduduk. Ide baru muncul: pertama, pinjaman kredit tidak perlu dibayar jika panen gagal, tetapi digunakan untuk irigasi pada tanah dan kebun yang digunakan untuk penanaman dan pesemaian benih, kedua, pemerintah menyediakan lapangan kerja di perusahaan keramik di Ngandong dan proyek kaca dan semen jika panen gagal. $^{14}$

\section{PERBAIKAN SISTEM IRIGASI}

Kemerosotan kesejahteraan penduduk Bojonegoro berkaitan erat dengan masalah pertanian penduduk, seperti Sistem irigasi, pemilihan bibit, pemupukan dsb. Sebelum tahun 1905

\footnotetext{
${ }^{14}$ Penders, baca bagian Epilog.
} 
penanganan masalah perbaikan pertanian ditangani oleh Institut Botani Nasional di Bogor, akan tetapi tidak berhasil, karena Supervisor Jawa (mantri) tidak memiliki latar belakang pendidikan formal, sehigga tak mengetahui metode modern dan diversivikasi program. ${ }^{15}$ Menurut Treub, keberhasilan dalam memperbaiki produksi pertanian perlu didirikan Desa landbouw scholen (sekolah pertanian desa), kursus-kursus pertanian, dan penyuluhan-penyuluhan pertanian. $^{16}$ Pada tahun 1900 Irigasi Teknik dan saluran pembuangan air di Bojonegoro masih sangat kurang. Irigasi yang ada pada saat itu hanya bisa mengairi $12 \%$ dari 79.000 bau sawah. Tingkat kesuburan tanah di Bojonegoro tergolong rendah. Hal ini dapat dipahami karena Irigasi di seluruh Jawa pada abad ke-19 yang tersedia hanya ada di daerah-daerah yang tanahnya subur.

\footnotetext{
${ }^{15}$ Penders, h.75.

${ }^{16}$ MSJ., h. LXX.
}

Sedangkan daerah yang tidak subur tidak disediakan irigasi teknik oleh pemerintah. Oleh sebab itulah hasil produksi padi termasuk rendah, dan di daerah-daerah yang tidak subur seperti Bojonegoro kekurangan air irigasi disebut-sebut sebagai penyebab kegagalan panen. $^{17}$ Kegagalan panen mnjadi salah satu penyebab terjadinya kemiskinan. Pada tahun 1922-1927 ratarata hasil padi kering adalah 15,80 pikol/ ha atau 10,31 ku gabah/ ha. ${ }^{18}$ Hasil produksi itu dapat dikatakan tidak tinggi, Kategori ini tentu kalau dibandingkan dengan daerah lain yang hasil produksinya sangat tinggi dan sangat rendah, Hasil tertinggi padi kering ialah 19.66 pikol/ha dan terendah adalah 11,37 ku/ha. Sedangkan apabila berbentuk gabah tertinggi adalah 12,83 dan terendah adalah 7,42 ku/ha. ${ }^{19}$ Apabila dibandingkan dengan daerah

\footnotetext{
${ }^{17}$ Baudet\& Brugmans,I.J. Politik Etis dan Revolusi Kemerdekaan. Jakarta: Yayasan Obor, 1987.,h.307. ${ }^{18}$ Sayogya, dan Cdollier. W. L. Budi daya PADI DI Jawa. Jakarta: Gramedia1986, h.180 ${ }^{19}$ Ibid.
} 
lain untuk tingkat kabupaten, Bojonegoro termasuk paling rendah, yaitu 124,84 kg/orang/tahun, Blora: 138,09 kg. Rembang: 137,81 kg, Tuban: $127,31 \mathrm{~kg} /$ orang/tahun. ${ }^{20}$

Perbaikan sistem irigasi di Bojonegoro merupakan perhatian utama pemerintah setempat. Ketika itu waduk yang sudah ada berjumlah lebih dari tujuh buah, yaitu: waduk Tlogo Haji, Koedoer, Plesoengan, Pacak, Panjang, Pasiman, Karangdinojo, dan waduk Metaunan, serta waduk kerjo. Pemilihan bibit, gagal panen, kesuburan tanah dsb. Hambatan perbaikan pertanian di Karesidenan Rembang umumnya dan Bojonegoro khususnya sebagaimana hasil pengamatan pihak Lanbouw Consullen (Penyuluh Pertanian) adalah pertama karena Irigasi teknis sangat kurang, dan kedua Tidak adanya kerjasama antara pihak Dinas Prtanian dan Pangreh Praja. ${ }^{21}$ Menurut Treub,

${ }^{20}$ Ibid.

${ }^{21}$ Mudji Hartono, Tesis 192.
Direktur Departemen Pertanian di Bogor, untuk memperbaiki pertanian perlu didirikan Desa Lanbouw Scholen. Sekolah Pertanian Desa, karena tenaga pertanian lulusan Bogor sangat sedikit yang dapat diangkat pada tahun 1908. Yang dimaksud Treub Sekolah itu adalah Desa Landbouw Shcolen, kemudian kursus-kursus dan penyuluhan-penyuluhan pertanian. $^{22}$ Sekolah Umum dianjurkan memasukkan mata pelajaran yang bersifat praktis seperti: bertani, pertukangan dan kerajinan tangan Departemen Pertanian di Bogor. Hal ini didasarkan pada suatu kenyataan bahwa Tamatan sekolah desa yang menjadi petani sangat sedikit. Dari 537 tamatan pada tahun 1917 hanya 101 orang yang terjun ke bidang pertanian 23 orang bekerja membantu sekolah itu $35 \%$ bekerja di penerangan pertanian pada Dinas Pertanian dan sisanya bekerja di tempat lain. Akibatnya adalah

\footnotetext{
${ }^{22}$ ANRI, Memorie Serah Jabatan 1921-1930, Jawa Tengah, LXX.
} 
sekolah tersebut tidak diminati oleh anak-anak. Maka fungsinya sebagai penyalur informasi digantikan oleh Kursus Guru Sekolah Desa yang ada di Bojonegoro. Harapannya adalah setelah selesaimengikuti pelajaran di kursus Guru-guru sekolah Desa, kemudian melanjutkan kursus selama 2 tahun serta praktek Lapangan dan yang terakhir mereka kemudian mengajarkan kepada para tamatan sekolah dasar. ${ }^{23}$ Perbaikan sistem Irigasi teknis merupakan bagian dari pelaksanaan kebijakan kesejahteraan. ${ }^{24}$

Perbaikan sistem Irigasi teknis merupakan bagian dari pelaksanaan kebijakan kesejahteraan atau Politik Etis. $^{25}$ Pemerintah Karesidenan Rembang sangat memperhatikan pembangunan sistem irigasi teknis di Bojonegoro sebab Bojonegoro merupakan daerah yang rawan banjir.

\footnotetext{
${ }^{23}$ Mudji Hartono. Op.Cit.,2002,h.193.

${ }^{24}$ J. Linblad, J.Thomas. (ed). Sejarah Ekonomi Modern Indonesia. Berbagai Tantangan Baru. Terjemahan M.Arief dan Bambang Purwanto..(Jakarta, LP3E 1998).,h.235-237

${ }^{25}$ Ibid.
}

Setiap tahunnya Bojonegoro dilanda bencana Banjir dan kekeringan. Maka Pemerintah mengeluarkan Keputusan No. 36 tanggal 8 Oktober 1902 tentang perbaikan sistem waduk. Semua waduk yang ada diperdalam, kecuali waduk Pajang yang belum lama berselang diperbaiki dengan menghabiskan dana sebesar 5.728 gulden. $^{26}$

Ketika itu waduk yang sudah ada berjumlah lebih dari 7 buah, yakni: waduk Tlogo Haji, Koedoer, pasinan, Blongsong, Karangdinojo, Metaunan Plesoengan, Pacal, Kerjo, Pengantin dan waduk Balong Soembak. ${ }^{27}$ Meskipun demikian Luas sawah yang dapat diairi masih sedikit, yaitu 3.227 bau. ${ }^{28}$ Perbaikan sistem irigasi masih sangat diperlukan di Bojonegoro.

Pada tahun 1900 Irigasi Teknik dan saluran pembuangan air di Bojonegoro masih sangat kurang Irigasi yang ada pada saat itu hanya bisa

\footnotetext{
${ }^{26}$ Penders, OpCit.,h.32., lihat juga Baudet. Locit.

${ }^{27}$ Penders, Ibid, h . 33.

${ }^{28}$ Penders LocCit.
} 
mengairi $12 \%$ dari 79.000 bau sawah. Ketika itu waduk yang sudah ada berjumlah tujuh buah, yaitu waduk Tlogo Haji, Koedoer, Pirang, Plesoengan, Pacal, Kerjo, dan waduk Panjang sendiri. Namun demikian luas sawah yang dapat diairi baru berjumlah 3227 bau pengairan ini berasal dari sumber air S. Solo. Perbaikan sistem Irigasi teknis terbentur pada masalah Solo Valley. Pada tahun 1893 Parlemen Belanda telah menerima rencana proyek Solo valley Proyek itu, yaitu tanah yang tidak subur, sungai dengan sifat alami sulit dikontrol. ${ }^{29}$ Dengan adanya proyek lembah solo, maka daerah-daerah di Bojonegoro seperti distrik Pelem dan Baureno memperoleh tambahan air pengairan Solo Valley merupakan proyek besar Tujuan utama proyek raksasa itu adalah untuk menghentikan timbunan pasir wegast. Mengubah Jalan laut kecil agar dapat dilalui perahuperahu ke pelabuhan Surabaya. Proyek

\footnotetext{
${ }^{29}$ Mudji Hartono, Op.cit h.,101..
}

itu meliputi: pertama mengubah mulut sungai Solo, dan kedua penggalian kanal untuk irigasi. Untuk proyek Solo Valley Semula Pemerintah menganganggarkan dana sebesar 19 milyar gulden, akan tetapi kemudian membengkak menjadi 38 milyar gulden, karena proyek itu bertambah dengan pembangunan kanalkanal untuk irigasi di daerah-daerah yang ada di lembah Sungai Solo. Khususnya di Bojonegoro, karena petani Bojonegoro tidak bisa menggunakan air irigasi dari kanal yang ada di desa Ngablak, 14 km dari kota Bojonegoro. Kanal itu hanya dapat mengairi sawahsawah petani di Surabaya bagian utara saja.

Hingga tahun 1925 kebutuhan air irigasi penduduk Bojonegoro dirasa masih sangat kurang. Hal ini diakui oleh Residen Rembang J.F. Hildering dalam laporannya Sebelum tahun $1925 .^{30}$ Waktu pengerjaannya pun bertambah

\footnotetext{
${ }^{30}$.L.M. Penders, Bojonegoro 1900-1942. A.Story of EndemicPoverty in. North East Java Indonesia.,h.29-30.
} 
lama tidak seperti diperkirakan semula, yaitu selesai sekitar 7-8 tahun ternyata menjadi lebih lama lagi.

Pembangunan irigasi solo valley tidak berdiri sendiri melainkan terintegrasi dengan pembuatan infrastruktur irigas yang lain, yakni waduk Dam, dan kanal, Pembangunan infrastuktur itu dimulai pada tahun 1905 beberapa waduk, yang dibangun saat itu adalah Waduk Tlogo Haji, waduk Pajang, waduk koedoer, Ketiga waduk itu disediakan dana sebesar 17.728 gulden, waduk yang lain yang dibangun di Bojonegoro adalah waduk Pengantin, Balong Soembak, Pirang, Plesoengan, Pacak, waduk kerjo, Khusus waduk Pacak dirancang selesai 4-5 tahun dengan dana sebesar 1,2 milyar gulden. Sedangkan pembangunan dam seperti dam Sokosewu yang ada di desa klepek disediakan biaya sebesar 3 milyar gulden. $^{31}$

\footnotetext{
${ }^{31}$ Ibid.h.33.
}

Sebelum tahun 1925 infrastruktur irigasi yang telah selesai dibangun selain waduk, juga berupa saluran irigasi yang utamanya untuk mengalirkan air dari sumber mata air Pirang dan Dunder, serta bangunan irigasi pada sungai Pacal, kali Kerjo, Kali Keduang, kali Cawak (kali ini merupakan anak sungai selatan Sungai Solo dan sekaligus merupakan batas antara wilayah Bojonegoro dan Gresik dan juga batas antara seksi pengairan Bojonegoro dan Lamongan dari Dinas Pengairan lembah Solo. Perlu diketahui bahwa antara kali Cawak dan Kali Kerjo terdapat 1800 bau sawah yang telah dapat diairi, berkat bangunan irigasi teknis tersebut, maka luas areal sawah yang dapat diairi bertambah menjadi 2500 bau, dan kali Tidu. Pada tanggal 30 Agustus tahun 1927 bangunan waduk yang dapat diselesaikan pembangunannya adalah waduk Pacal yang terletak di desa Tretes (Onder 
distrik Sugihkuranang di sebelah selatan

S. Pacal Waduk itu diperkirakan dapat menampungair 40 milyar meter kibek dan dapat dipakai untuk mengairi lebih dari 20.000 bau sawah di distrik Palem dan Bojonegoro. Di samping itu juga dapat dipakai untuk menampung kelebihan air dari bagian selatan distrik Baureno. $^{32}$

$$
\text { Setelah pembangunan }
$$

infrastruktur pertanian di Bojonegoro, maka hasil produksi padi mengalami kenaikan pada tahun 1930-an. ${ }^{33}$ Meskipun demikian di Bojonegoro masih sering muncul fenomena keresahan penduduk dan kekhawatiran kekurangan pangan serta mempertahankan hidup keluarga sebagaimana dilaporkan bahwa kegagalan panen menambah angka kriminalitas. $^{34}$ Kegagalan panen di Bojonegoro tahun 1904-1906 mengakibatkan kelaparan di berbagai

\footnotetext{
32 Penders, Ibid.,h.34.

${ }^{33}$ Mudji Hartono,Op.Cit.,h.11.

${ }^{34}$ Op.cit SMJ. H. LXX.
}

distrik. Hal ini telah dilaporkan oleh Residen, Fraenkekel kepada Ggubernur Jenderal. Laporan dari Residen Fraenkel tahun 1904 menjadi suatu pertanda kekhawatiran pemerintah. Oleh karena itu pemerintah mengeluarkan dana sebesar 30.000 gulden untuk membeli bibit jagung. ${ }^{35}$

\section{EDUKASI}

Pendidikan modern merupakan satu aspek penting dari Politik Etis. Opini Mayoritas di kalangan pembuat kebijaksanaan itu mengatakan bagaimanapun di lapisan atas masyarakat memerlukan standar pendidikan yang ekuivalen dengan pendidikan Belanda. Sedangkan lapisan masyarakat yang lain hanya memerlukan instruksi ringkas yaitu $3 \mathrm{R}$.

Pemerintah selain melakukan Pembanguan sektor pertanian, khususnya Irigasi juga melaksanakan pembangunan sektor pendidikan sementara itu perhatian pemerintah

\footnotetext{
${ }^{35}$ Penders.,h.25.
} 
terhadap program emigrasi terlihat tidak dapat berjalan dengan baik. Pada tahun 1930, dari jumlah penduduk 483791 jiwa, yang bersedia mengikuti program Transmigrasi ke luar Jawa hanya ada 24385 orang. Jumlah itu lebih kecil dibandingkan Orang Bojonegoro yang pindah ke Semarang untuk mencari nafkah, yaitu ada 29.525 orang Orang. ${ }^{36}$ Kebanyakan orang Bojonegoro enggan pergi jauh meninggalkan tanah kelahirannya, mereka hanya bersedia pergi ke daerah terdekat dan mereka kebanyakan memiliki anggapan bahwa tanah miliknya yang sempit masih bisa memberikan kehidupan.seluruh keluarganya. ${ }^{37}$ Oleh karena itu walaupun ada daya tarik yang berupa pemberian tanah secara gratis dari pemerintah Hindia Belanda, Penduduk Bojonegoro rupanya tidak terarik untuk berangkat transmigrasi ke luar Jawa. Penduduk Bojonegoro pergi untuk mencari nafkah

\footnotetext{
${ }^{36}$ Mudji Hartono,Op.Cit. ,h.47

${ }^{37}$ Mudji Hartono, Ibid.
}

ke daerah terdekat yang menjadi tujuan orang-orang Bojonegoro antara lain adalah Kudus, Ngawi, Madiun, Kediri, Pati, dan Semarang serta Surabaya. ${ }^{38}$ Pelaksanaan program pembangunan Edukasi di Bojonegoro sebagai wujud keseriusan Pemerintah kolonial Belanda dalam meningkatkan kesejahteraan penduduk setempat. memajukan pendidikan di Bojonegoro terlihat pada banyaknya sekolah yang didirikan oleh Pemerintah. Pada tahun 1920 terdapat pengembangan pendidikan di Bojonegoro, ada 140 buah Sekolah Desa. 51 buah sekolah Tweede klasse Schoolen Pada tahun 1927 jumlah sekolah di Bojonegoro meningkat menjadi 148, dan 182 buah sekolah Desa, 2 buah diantaranya Sekolah Khusus wanita yang mengajarkan bidang ekonomi, menjahit, pekerjaan tangan, 18 buah diantaranya ialah sekolah Tweede klasse Scholen di seluruh Residensi Rembang terdapat

\footnotetext{
${ }^{38}$ Ibid.,h.118.
} 
sekolahan Vervolgscholen sama halnya di daerah lain di jawa. Sistem Persekolahan di Bojonegoro bersifat dualistik, artinya ada pembedaan dua sistem persekolahan, di satu pihak terdapat Sekolahan dengan Pengantar bahasa Belanda, dan di pihak lain ada pendidikan yang vernakuler, ${ }^{39}$ atau pendidikan dengan unsur bahasa daerah.

Pendidikan modern merupakan satu aspek penting dari Politik Etis. Opini mayoritas di kalangan pembuat kebijaksanaan menyatakan bagaimanapun pada lapisan atas masyarakat yang memerlukan standar pendidikan yang ekuivalen dengan Sekolah Belanda. Mayoritas masyarakat yang lain hanya instruksi ringkas yang diperlukan, yakni 3R sebagai hasil dari struktur pendidikan yang dualistik. Pendidikan yang tampak adalah sebagian dari pendidikan tersebut mempunyai sistem pendidikan berbahasa Belanda, yang lain merupakan

${ }^{39}$ Penders, Op.Cit. h.35. sistem sekolah $\quad$ Vernakuler (berunsurkan bahasa daerah). Perhatian utama pemerintah kolonial Belanda adalah untuk menggalakkan masuknya anak-anak golongan atas Indonesia ke sekolah yang berbahasa Belanda. Namun ternyata dijumpai juga banyak anak dari golongan menengah dan bahkan kelas bawah yang berhasrat masuk ke sekolah tersebut. Orang tua mereka menyangupi soal pembiayaan. Pejabat inquiri pada tahun 1926 menemukan dari 52.600 anak di sekolah pribumi Belanda, 66\% di antaranya tidak memenuhi norma pendaftaran asli. $^{40}$

Tujuan utama anak-anak pribumi masuk ke sekolah Belanda adalah untuk mendapatkan pekerjaan sebagai pejabat sipil kolonial yang memiliki prestise. Di tingkat Kabupaten kebutuhan tenaga yang berpendidikan terdapat untuk menempati jabatan sebagai Kliwon, Menteri, dan juru tulis, sedangkan di

\footnotetext{
${ }^{40}$ Penders., Ibid.
} 
tingkat distrik tenaga terdidik ditempatkan sebagai Menteri Ari, Jogorekso (pesuruh), Menteri Sambong (pengairan Mantri polisi serta pembantu-pembantu nya).

Di Bojonegoro juga terdapat Landbouw Consulent yang juga memerlukan tenaga terdidik Bojonegoro dijadikan Distrik Hutan karena itu memerlukan tenaga terdidik. Selain itu di Bojonegoro juga ada berbagai dinas, seperti Dinas Kehutanan, Kesehatan, Pertanian, dan Dinas Pekerjaan Umum. Di dalam lembaga tersebut Pemerintah menempatkan tenaga-tenaga yang berijazah di bidang teknik dan keahlian. Apabila mereka gagal maka alternatifnya menjadi sekretaris, mandor, dan atau sekretaris desa. Hal ini menunjukkan sifat pendidikan kolonial yang dkenal dengan sebutan: Utiliteit Onderwijs. $^{41}$ Kiranya hal inilah yang menjadi motifator yang sangat kuat bagi masyarakat. Menjelang tahun 1920-an mereka yang berbekal pendidikan Belanda jumlahnya telah melebihi target yang ditentukan pemerintah kolonial sehingga Komisi Khusus membatasi anak-anak yang memasuki sekolah berbahasa Belanda, adapun yang diperbolehkan memasuki sekolah berbahasa Belanda adalah hanya dari kalangan atas dan sebagian yang telah diterima dialihkan ke sekolah Vernakuler dan berbagai sekolah teknik yang lain. Meskipun Sekolah Vernakuler mendapat kritik karena sistem sekolah itu gagal untuk memberikan berbagai ajaran yang luas sebagai objek mayor. Pejabat pemerintah sering menggunakan paksaan, "perintah halus" agar penduduk Desa bersedia mendirikan sekolahan untuk komunitasnya.

$$
\text { Sangat menarik untuk }
$$
diperhatikan adalah bahwa di Bojonegoro ada fenomena yang berupa tuntutan belajar dan pengetahuan bahasa

\footnotetext{
${ }^{41}$ Hatta., h. 98.
} 
Belanda modern yang amat kuat. Hal ini mendorong berdirinya ELS (Eruropeese Logere School ) dan HIS ( Holands Inlandsche School). Adapun siswa yang bisa memasuki sekolah HIS dan ELS adalah anak-anak orang Belanda, Eurasians, dan anak-anak pribumi dari kelas atas. ${ }^{42}$ Di kota Bojonegoro hingga tahun 1906 terdapat sekolahan Vernakuler, yakni Eerste klasse School yang lama belajarnya 5 tahun. Selain itu terdapat pula sekolah Tweede Klasse School dan sekolah swasta non subsidi Khusus untuk golongan atas yang mengajarkan 3R, Geografi, Sejarah, dan ilmu alam, menggambar dan meneliti disamping itu di luar kota juga ditemukan adanya sekolah seperti di kota, di distrik Pelem ada sekolah Tweede Klasse School, di Baureno telah didirikan sekolah swasta bersubsidi, dan di Tambakrejo terdapat sekolah swasta tidak bersubsidi. Pada umumnya pelajar berasal dari anak-anak

${ }^{42}$ Penders.,h.
Priyayi, Kepala Desa, Pedagang, dan dari lingkungan keluarga yang memiliki kedudukan Sosial tinggi di kampung. ${ }^{43}$

Sejak awal tahun 1920-an Pemerintah kolonial Belanda berusaha keras menyebarkan Sekolah Desa, untuk itu pemerintah menyediakan dana dan pengakomodasiannya dilakukan tahun 1940-an. Jumlah anak di Sekolah Desa ada 15197 anak dan 2766 anak diantaranya adalah anak perempuan. ${ }^{44}$ Dalam tahun 1929-1930 Pemerintah masih merencanakan untuk menambah 15 buah sekolah per tahunnya dan dana yang dianggarkan sebesar 10 juta gulden. Pemerintah menargetkan dalam waktu 4 tahun di Bojonegoro terdapat 250 buah sekolahan. $40 \%$ anak Usia 6-9 tahun dimasukkan ke sekolah Vernakuler. $^{45}$ Meskipun Sekolah Vernakuler berkembang secara spektakuler, namun Sekolah Vernakuler itu dikritik oleh orang-orang Belanda

\footnotetext{
${ }^{43}$ Penders.,h.70.

${ }^{44}$ Ibid.,h.47.

${ }^{45}$ Penders..Ibid.
} 
karena keluar dari kebiasaan hidup kaum pribumi, seperti Hari Libur sekolah yang tidak cocok karena tidak memperhitungkan musim tanam, harihari besar agama, dan festival. Kurikulum dinilai terlalu intelektual. Persiapan untuk pendidik kurang baik karena tidak sesuai dengan kehidupan riil. Karakter Barat mendominasi sekolah vernakuler, maka sekolah vernakuler gagal mengajarkan kehidupan yang nyata dan penting bagi penduduk pribumi.

\section{BOJONEGORO PADA AKHIR PEMERINTAHAN HINDIA} BELANDA.

Situasi Bojonegoro pada akhir tahun 1930-an belum mengalami perubahan yang signifikan dalam arti belum terjadi perbaikan kemakmuran. Berbagai Pers Belanda memuat beritaberita tentang masalah-masalah yang terdapat di Bojonegoro, seperti soal penurunan produksi pertanian, soal gagal panen, kelaparan, wabah penyakit, kekurangan gizi dan berita itu beredar di lingkungan Parlemen Belanda Kegagalan panen di Bojonegoro tidak saja terjadi pada tanaman padi melainkan juga pada tanaman kedua, seperti jagung dan tembakau. Kegagalan panen itu sudah dialami oleh petani Bojonegoro sejak tahun 1888, Gagal panen saat itu berlanjut pada tahuntahun berikutnya, seperti tahun 1889 sampai dengan 1891 dan tahun 19041906. Adapun sebab-sebab kegagalan panen tersebut adalah kekurangan air di musim penghujan, wabah penyakit tanaman, tanah-tanah diberokan ${ }^{46}$ dan musim tidak stabil. Tidak adanya solusi telah menimbulkan perdebatan di kalangan pejabat kolonial, Sehubungan dengan itu Van Mook memerintahkan mengkaji masalah Bojonegoro dengan cara membentuk tim yang terdiri dari pejabat Departemen Hubungan Ekonomi, pejabat Departemen

\footnotetext{
${ }^{46}$ Algemen van Resident Rembang,1889, 1890,18
} 
Transpotasi dan air, dan pejabat Propinsi. Tugas tim ini adalah untuk mengeluarkan Bojonegoro dari bencana ekonomi yang kronik. Untuk mengatasi kegagalan panen di Bojonegoro dalam tahun $\quad 1936-1938 . \quad$ Pemerintah menerapkan kebijakan, yaitu pertama Pinjaman kredit pertanian dihapuskan jika petani gagal panen, anngsuran kredit tersebut dialihkan untuk keperluan irigasi, kedu pemerintah menyediakan lapangan kerja baru, yaitu mendirikan pabrik keramik di Ngandong, pabrik kaca di Teben dan pabrik semen di Gresik, dan pabrik rokok serta cerutu digalakkan sebagai industri rumah tangga Gresik. Disamping itu pemerintah menggalakkan program transmigrasi.

\section{KESIMPULAN}

Kabupaten Bojonegoro terletak di wilayah Propinsi Jawa Timur yang terus menerus atau hampir setiap tahun dilanda bencana banjir. Daerah itu sudah sejak tahun 1888 menjadi langganan banjir dari meluapnya sungai Solo. Memang daerah itu merupakan daerah rawan banjir. Selain itu Bojonegoro sering kali dilanda kekurangan bahan pangan sebagai akibat gagal panen yang kronis. Pada masa Pemerintah Hindia Belanda, di Bojonegoro kerap kali terjadi kemunduran pertanian. Oleh karena itu Perbaikan sistem pertanian menjadi tujuan utama pemerintah. Realisasinya adalah dengan memperbaiki sistem irigasi, Penyuluhanpenyuluhan pertanian. Pembangunan infrastruktur irigasi dapat dikatakan sangat banyak, yaitu lebih dari 17 buah bangunan, yang berupa waduk, bendungan, saluran air, dan kanal. Anggaran yang dikeluarkan pemerintah sangat besar. Jumlah areal tanam yang dapat diairi bertambah luas. Dalam tahun 1930-an diketahui terjadi kenaikan produksi beras di Bojonegoro. Dalam sektor pendidikan banyak bangunan 
sekolah didirikan, direncanakan sebanyak 250 buah sekolahan dibangun untuk kepentingan rakyat. Meskipun anak-anak dari golongan bawah belum memiliki kesempatan yang sama dengan golongan elit.

Perbaikan kesejahtereaan penduduk dilakukan juga dengan cara perbaikan sistem pendidikan, bagaimanapun dalam pelaksanaan pendidikan terdapat diskriminasi, sehingga golongan bawah tidak memiliki kesempatan yang sama dengan golongan elit, menggiatkan program transmigrasi, dan membuka lapangan kerja baru. Hal ini mengakibatkan kemerosotan kesejahteraan penduduk. Sejalan dengan program Politik Etis, maka Pemerintah Kolonial Belanda merealisasikan program itu dengan serius. Dalam upaya meningkatkan standar hidup penduduk Pemerintah mengutamakan perbaikan sistem pertanian, Pemerintah memfokuskan pada perbaikan sistem irigasi, sebanyak lebih dari 17 buah bangunan infrastruktur irigasi dibangun sejak awal abad ke-20, yakni berupa: bangunan waduk, dam, kanal, dan saluran air irigasi. Pembangunan infrastruktur itu didasarkan pada pendapat-pendapat, bahwa penyebab kegagalan panen karena kekurangan air di musim penghujan.

Sesudah Perbaikan sistem irigasi dilakukan, kemudian dari Pihak departemen pertanian di Bogor masih pesimis, mereka berpendapat bahwa perbaikan pertanian akan berhasil jika penduduk memiliki pengetahuan yang cukup tentang pertanian, karena itu langkah selanjutnya perlu didirikan sekolah pertanian desa (Desa Lanbouw scholen).

Pelaksanaan Politik Etis di Bojonegoro merupakan bukti keseriusan Pemerintah kolonial Belanda dalam upaya meningkatkan ekonomi penduduk 
setempat. Perbaikan sistem irigasi di Bojonegoro merupakan suatu bagian dari pelaksanaan kebijakan kesejahteraan. Pembangunan infrastruktur irigasi dan perbaikan sistem irigasi teknis di Bojonegoro jumlahnya cukup banyak dan biayanya pun sangat besar. Jumlah bangunan infrastruktur irigasi, seperti: waduk, dam, dan kanal ada sekitar 17 buah lebih. Jumlah ini menunjukkan bahwa perbaikan sistem irigasi teknis lebih banyak jumlahnya dari pada daerah lain di wilayah karesidenan Rembang. Di Blora misalnya, hanya dibangun 2 buah waduk, yaitu waduk Geneng dan waduk Tempuran. Begitu pula di Kabupaten Rembang, menurut laporan Residen J.Habemma dalam Memorie Van Overgave bangunan irigasi teknis masih sangat kurang. ${ }^{47}$ Tentang Pendidikan,

${ }^{47}$ MVO, J.Habemma,h.22.
Pemerintah Hindia Belanda sangat memperhatikan bidang pendidikan untuk semua lapisan masyarakat. Pengembangan pendidikan ditandai oleh banyaknya sekolahan yang didirikan pemerintah di Bojonegoro. Sedangkan untuk program transmigrasi, tampaknya mengalami hambatan, karena penduduk Bojonegoro tidak merespon dengan positif. Orang-orang Bojonegoro tidak berminat meninggalkan tanah kelahirannya untuk pergi jauh ke luar Jawa. Mereka hanya bersedia pindah ke daerah terdekat untuk mencari nafkah, seperti ke daerah Ngawi, Pati, Kediri, Madiun, Surabaya, dan paling banyak di Semarang

\section{DAFTAR PUSTAKA}

Algemen van Resident Rembang,1889, 1890,1891 .

ANRI. Memorie Serah Jabatan ( 1921 1930 ) Jawa Tengah). Jakarta : ANRI, 1977. 
Baudet\& Brugmans,I.J. Politik Etis dan

Revolusi Kemerdekaan.Jakarta: Yayasan Obor, 1987.

Hatta. Kumpulan Karangan. Djakarta: Penerbitan dan Balai Buku Indonesia, 1954.

Linblad, J.Thomas. ( ed ). Sejarah Ekonomi Modern Indonesia. Berbagai Tan tangan Baru. Terjemahan M.Arief dan Bambang Purwanto.. Jakarta, LP3E 1998 ). Penders, C.L.M. Bojonegoro 1900-1942. A.Story of Endemic Poverty in . North East Java In donesia.

Singapura: Gunung Agung, 1984.
Mudji Hartono Pertanian Tanaman Pangan di Karesidenan Rembang 1900- 1928., Tesis. Tidak diterbitkan Pada Universitas Gadjah Mada, 2002. MVO, Residen Rembang, J . Habbema. Sayogya , dan Cdollier. W. L. Budidaya Padi di Jawa. Jakarta : Gramedia, 1986).

Vries, Egbert, de . Masalah -Masalah Petani Jawa. Jakarta: Bhratara, 1972. Pertanian dan

Kemiskinan di Jawa, Jakarta : Obor, 1985. 